\section{Kidney \\ Blood Pressure Research}

Kidney Blood Press Res 2015;40:443-451

DOI: 10.1159/000368520

Published online: August 22, 2015

Accepted: July 14, 2015

\title{
Discordant Clinical Course of Vitamin- D-Hydroxylase (CYP24A1) Associated Hypercalcemia in Two Adult Brothers With Nephrocalcinosis
}

\author{
Tilman Jobst-Schwan ${ }^{a} \quad$ Andrea Pannes ${ }^{b} \quad$ Karl Peter Schlingmann ${ }^{c}$ \\ Kai-Uwe Eckardta Bodo B. Beck ${ }^{\mathrm{b}} \quad$ Michael S. Wiesener ${ }^{\mathrm{a}}$ \\ aDepartment of Nephrology and Hypertension, Friedrich-Alexander Universität Erlangen-Nürnberg, \\ Erlangen-Nürnberg; 'DInstitute of Human Genetics, University of Cologne Medical Center, Cologne; \\ 'University Children's Hospital, Muenster, Germany
}

\section{Key Words}

Hypercalciuria $•$ Nephrolithiasis $•$ Kidney stones $•$ Hypervitaminosis $•$ Calcium metabolism

\begin{abstract}
Background/Aims: Hypercalcemia can result in nephrocalcinosis/nephrolithiasis and may lead to renal failure. Idiopathic infantile hypercalcemia is caused by mutations of the CYP24A1 gene, which regulates vitamin D activity. Classically infants present with hypercalcemia. Recently, a number of individuals have been reported with late onset clinical manifestation or late diagnosis in adulthood. All these patients are believed to show hypercalciuria. Methods: We report a 24 year old patient of healthy consanguine parents. Genetic analysis was performed by Sanger sequencing of the CYP24A1 gene in the index patient and targeted exon 2 analysis of all other family members. Results: The patient was hospitalized with severe malaise during an acute EBV-infection. He showed hypercalcemia $>3 \mathrm{mmol} / \mathrm{l}$ and acute, hypovolemic renal failure with profound nephrocalcinosis, but no hypercalciuria. Genetic workup revealed a homozygous loss-of-function mutation p.E143del in the CYP24A1 gene. His clinically asymptomatic brother showed nephrocalcinosis of lesser degree. Repeatedly, low parathyroid hormone levels were detected in both brothers. Conclusion: This family displays the highly variable phenotype of CYP24A1 biallelic mutation carriers. CYP24A1 associated disease is an important differential diagnosis for the workup and counseling of infants as well as adults with hypercalcemia since a proper genetic diagnosis may result in therapeutic consequences.
\end{abstract}




\section{Kidney \\ Blood Pressure Research}

Kidney Blood Press Res 2015;40:443-451

DOI: $10.1159 / 000368520$

Published online: August 22, 2015

(C) 2015 S. Karger AG, Basel

www.karger.com/kbr

Jobst-Schwan/Pannes/Schlingmann/Eckardt/Beck/Wiesener: Phenotype Variability in CYP24A1 Disease

\section{Introduction}

Nephrocalcinosis (NC) is characterized by the deposition of calcium in the kidney parenchyma and tubules, which is usually situated in the medulla and visible on routine clinical imaging, such as ultrasound and computed tomography (CT), and if severe also on conventional abdominal X-ray. In $20 \%$ of premature infants, NC is a coincident finding upon abdominal ultrasound [1]. NC is also noted in about $1.7 \%$ of autopsies [2] and in approximately $50 \%$ of cases this finding can be attributed to malignancy. The etiology of the rest remains mostly unclear, yet clarification of its underlying cause is important, since progressive disease can lead to renal insufficiency and also bears the risk of extrarenal calcification. Histopathologically calcium oxalate (oxalosis; seen in primary and secondary hyperoxaluria) needs to be distinguished from calcium precipitates free of oxalate. Renal calcium deposition as NC and/or recurrent urolithiasis typically occurs in disorders of disturbed calcium or phosphate homeostasis with increased urinary excretion of calcium or phosphate.

Causes for hypercalcemia associated NC can be genetic or acquired. Important examples of the former are Williams-Beuren syndrome (WBS); elastin gene deletions, familial isolated hyperparathyroidism (FIHP), multiple endocrine neoplasia (MEN1) and mutations in the calcium sensing receptor (CASR). Examples of the latter are malignancy, sarcoidosis, drugs (e.g. thiazide diuretics) and vitamin D therapy. Differential diagnosis of disorders associated with hypercalcemia are listed in Table 1.

Clinical workup for NC routinely includes the acid-base status, vitamin D levels, parathyroid hormone (PTH), urinary excretion of calcium, phosphate, oxalate and citrate, as well as the measurement of serum calcium and phosphate. The interpretation of any of these parameters may be hampered by renal insufficiency, as well as dietary influences and a high diurnal variation of urinary excretion parameters. Therefore, careful clinical assessment of extrarenal manifestation, age at onset of symptoms and the family history may pose important clues towards clarification of the disease.

Among the growing list of possible causes of NC, mutations in the cytochrome P450 24-hydroxylase gene (CYP24A1, location 20q13.2, OMIM 143880) have been recently recognized as the major cause of autosomal recessive idiopathic infantile hypercalcemia (IHH) [3].

The CYP24A1 gene encodes the mitochondrial enzyme CYP24A1 which contains a cytochrome P450 domain responsible for inactivation of $1 \alpha, 25(\mathrm{OH})_{2} \mathrm{D} 3$ and 25OHD3, resulting in $1 \alpha, 24,25(\mathrm{OH})_{3} \mathrm{D} 3$ and $24,25(\mathrm{OH})_{2} \mathrm{D} 3$.The CYP24A1 enzyme is inhibited in a feedback mechanism by $1 \alpha, 24,25(\mathrm{OH})_{3} \mathrm{D} 3$ and stimulated by $1 \alpha, 25(\mathrm{OH})_{2} \mathrm{D} 3$ and PTH [3]. Biallelic mutations of CYP24A1 cause accumulation of the active form of vitamin D resulting in hypercalcemia (and PTH suppression), increased filtration and renal tubular reabsorption of calcium, and finally deposition of calcium precipitates in the urogenital tract.

In addition to IHH CYP24A1 mutations are increasingly identified in older patients with a subclinical course or late manifestation of disease which is not always found in relation to vitamin D intake (Table 2).

We report here two discordant brothers bearing a homozygous CYP24A1 in frame deletion, without apparent hypercalciuria, but with severe nephrocalcinosis, chronic renal failure and serious hypercalcemia in the index patient. Remarkably, despite documented vitamin D supplementation in infancy none of the brothers came to medical attention in childhood. This report emphasizes the importance of a precise molecular diagnosis with regard to proper treatment and counseling (family, life style and diet) in the era of widespread vitamin D supplementation. 


\section{Kidney \\ Blood Pressure Research}

Jobst-Schwan/Pannes/Schlingmann/Eckardt/Beck/Wiesener: Phenotype Variability in CYP24A1 Disease

Table 1. Differential diagnosis of inherited and acquired disorders associated with hypercalcemia

\begin{tabular}{|c|c|c|c|}
\hline Disorder & Gene & $\begin{array}{l}\text { Inheri- } \\
\text { tance }\end{array}$ & Hints and hallmarks \\
\hline $\begin{array}{l}\text { Williams-Beuren } \\
\text { syndrome }\end{array}$ & $\begin{array}{l}\text { continuous gene } \\
\text { deletion syndrome } \\
(1.55 \mathrm{Mb} \text { including } \\
E L N, \text { LIMK1,RFC2); } \\
7 \mathrm{q} 11.23\end{array}$ & $\begin{array}{l}\text { mostly } \\
\text { sporadic }\end{array}$ & $\begin{array}{l}\text { multisystemic developmental disorder with } \\
\text { mental retardation, distinctive neuropsychological } \\
\text { profile "happy party manner", variable } \\
\text { cardiovascular findings (aortic stenosis), } \\
\text { abnormalities of renal tract and connective tissue, } \\
\text { temporary hypercalcemia and hypercalciuria, } \\
\text { NC/UL }\end{array}$ \\
\hline $\begin{array}{l}\text { (vitamin D induced) } \\
\text { infantile } \\
\text { hypercalcemia (IHH), } \\
\text { hypercalciuria and } \\
\text { nephrocalcinosis } \\
\text { (formerly known as } \\
\text { idiopathic nonsyndromal } \\
\text { infantile hypercalcemia } \\
\text { or Lightwood type) }\end{array}$ & $\begin{array}{l}\text { CYP24A1/25 } \\
\text { hydroxyvitamin } \\
\text { D24-hydroxylase, } \\
\text { the key } \\
\text { mitochondrial } \\
\text { protein for } \\
\text { degradation of } \\
1 \alpha, 25(\mathrm{OH})_{2} \mathrm{D} 3 \text {, the } \\
\text { physiologically } \\
\text { active form of } \\
\text { vitamin } \mathrm{D} 3 ; 20 q 13.2\end{array}$ & ar & $\begin{array}{l}\text { increased sensitivity to regular (supplemental) } \\
\text { and excess doses of vitamin D resulting in severe } \\
\text { symptomatic hypercalcemia (failure to thrive, } \\
\text { hypotonia, dehydration, acute renal failure) with } \\
\text { hypercalciuria and nephrocalcinosis and/or } \\
\text { nephrolithiasis. } \\
\text { wide phenotypic spectrum associated with } \\
\text { CYP24A1 mutations. Usually low/suppressed } \\
\text { intact PTH levels and } 1 \alpha, 25(\mathrm{OH})_{2} \mathrm{D} 3 \text { levels at the } \\
\text { upper normal limit }\end{array}$ \\
\hline $\begin{array}{l}\text { Primary hyper- } \\
\text { parathyroidism }\end{array}$ & & & $\begin{array}{l}\text { prevalence of 3:1000 in the general population } \\
\text { with a female-to-male ratio of ca. } 3: 1\end{array}$ \\
\hline
\end{tabular}

\section{(PHPT):}

\# sporadic PHPT

\section{\# MEN1 syndrome- associated PHPT}

\# Familial isolated hyperparathyroidism (FIHP)

\# Hyper-parathyroidism 2 (HRPT2)

\# neonatal severe primary hyperparathyroidism (NSHPT)

Metaphyseal chondrodysplasia, Murk Jansen type single parathyroid adenoma, not

inherited.

Menin, 11q13

1. Menin, $11 \mathrm{q} 13$

(20\%)

2. CASR, 3q21

(10-20\%)

HRPT2 (Parafibro-

min, 1q31.3; rare)

CASR, 3q21 n.a.

symptoms of hypercalcemia with peak incidence in the sixth decade of life

ad

ad

- $4 \%$ of all PHPT, no sex prevalence with earlie onset two to three decades earlier than sporadic PHPT without other associated endocrinopathies in two or more individuals in one family.

ad inactivating mutations in CaSR hypocalciuric hypercalcemia

ad multiple ossifying fibromas of the mandible and maxilla; recurring pancreatitis,

ar very severe hypercalcemia

\begin{tabular}{ll}
\hline Chronic kidney disease & n.a \\
\hline Granulomatous disease & n.a.
\end{tabular}

n.a.
PTHR1

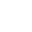

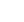

ad

ad severe postnatal short stature, $\mathrm{NC}$ normal PTH levels, Hypercalcemia, Hypophosphatemia Hypercalciuria, Hyperphosphaturia

n.a. Secondary hyperparathyroidism

n.a. Elevated calcitriol levels/no reduction by increased calcium intake, mostly in tuberculosis and sarcoidosis: elevated serum angiotensin converting enzyme, positive tuberculin skin test, pathologic chest radiograph/HRCT

\begin{tabular}{llll}
\hline Thyrotoxicosis & n.a. & n.a. & Suppressed TSH, elevated T3/T4 \\
\hline Cancer & n.a. & n.a. & $\begin{array}{l}\text { osteolytic metastases (e.g. breast cancer, multiple } \\
\text { myeloma, prostate cancer), ectopic secretion of } \\
\text { parathyroid-related hormone or PTH (e.g. small } \\
\text { cell lung cancer, squamous cell carcinoma, renal } \\
\text { cancer, ovarian cancer, non-Hodgkin lymphoma) }\end{array}$ \\
$\begin{array}{llll}\text { Vitamin D/Vitamin A } \\
\text { excess }\end{array}$ & n.a. & n.a. & $\begin{array}{l}\text { Intake of dietary supplements } \\
\text { Drugs }\end{array}$ \\
& n.a. & n.a. & $\begin{array}{l}\text { L-thyroxine, estrogen, antiestrogen (e.g. } \\
\text { tamoxifen), calcium carbonate (milk alkali } \\
\text { syndrome), lithium, thiazide diuretics, teriparatid }\end{array}$ \\
\hline ad autosomal dominant, ar autosomal recessive, n.a. not applicable
\end{tabular}




\section{Kidney \\ Blood Pressure Research}

Jobst-Schwan/Pannes/Schlingmann/Eckardt/Beck/Wiesener: Phenotype Variability in CYP24A1 Disease

Table 2. synopsis of currently published CYP24A1 mutations and clinical description

\begin{tabular}{|c|c|c|c|c|c|c|}
\hline $\begin{array}{l}\text { Family } \\
\text { patient }\end{array}$ & onset & NC/UL & $\mathrm{HCa}, \mathrm{HCu}$ & genotype & $\begin{array}{l}\text { Vit D } \\
\text { Suppl }\end{array}$ & publication \\
\hline $1-1$ & $6 \mathrm{mo}$ & $\mathrm{NC}$ & $\mathrm{HCa} ; \mathrm{HCu}$ & $\begin{array}{l}\text { pA475fs*25/ } \\
\text { pA475fs*25 }\end{array}$ & + & Schlingmann, N Engl J Med, 2011 [3] \\
\hline $2-1$ & $6 \mathrm{mo}$ & $\mathrm{NC}$ & $\mathrm{HCa}, \mathrm{HCu}$ & pE143del/pE151* & + & Schlingmann, N Engl J Med, 2011 \\
\hline $2-2$ & asympt & $\mathrm{NC}$ & $\mathrm{HCa}, \mathrm{HCu}$ & pE143del/pE151* & + & Schlingmann, N Engl J Med, 2011 \\
\hline $3-1$ & $8 \mathrm{mo}$ & $\mathrm{NC}$ & $\mathrm{HCa}, \mathrm{HCu}$ & pL309S/pR396W & + & Schlingmann, N Engl J Med, 2011 \\
\hline $3-2$ & asympt & $\mathrm{NC}$ & $\mathrm{HCu}$ & pL309S/pR396W & - & Schlingmann, N Engl J Med, 2011 \\
\hline $4-1$ & $11 \mathrm{mo}$ & $\mathrm{NC}$ & $\mathrm{HCa}, \mathrm{HCu}$ & pE143del/pR159Q & + & Schlingmann, N Engl J Med, 2011 \\
\hline $5-1$ & $7 \mathrm{mo}$ & $\mathrm{NC}$ & $\mathrm{HCa}, \mathrm{HCu}$ & pE322K/pR396W & + (bolus) & Schlingmann, N Engl J Med, 2011 \\
\hline $6-1$ & $3.5 \mathrm{mo}$ & $\mathrm{NC}$ & $\mathrm{HCa}, \mathrm{HCu}$ & pE322K/pR396W & + (bolus) & Schlingmann, N Engl J Med, 2011 \\
\hline $7-1$ & $2.3 \mathrm{mo}$ & $\mathrm{NC}$ & $\mathrm{HCa}, \mathrm{HCu}$ & pR396W/p.R396W & + (bolus) & Schlingmann, N Engl J Med, 2011 \\
\hline $8-1$ & $1.3 \mathrm{mo}$ & $\mathrm{NC}$ & $\mathrm{HCa}, \mathrm{HCu}$ & c.445_449+1delATCCTG & + (bolus) & Schlingmann, N Engl J Med, 2011 \\
\hline $9-1$ & $10 \mathrm{mo}$ & $\mathrm{NC}$ & $\mathrm{HCa}, \mathrm{HCu}$ & pE143del/pE143del & + & Dauber, J Clin Endocr Metab, 2012 [11] \\
\hline $10-1$ & $36 \mathrm{mo}$ & $\mathrm{NC}$ & $\mathrm{HCa}, \mathrm{HCu}$ & $\mathrm{pE} 143 \mathrm{del} / \mathrm{pL} 148 \mathrm{P}$ & $-(?)$ & Nesterova, CJASN, 2013 [9] \\
\hline $11-1$ & $4 \mathrm{mo}$ & $\mathrm{NC}$ & $\mathrm{HCa}, \mathrm{HCu}$ & pR396W/p.R396W & + & Fencl, Eur J Pediatr, 2013 [12] \\
\hline $12-1$ & $5 \mathrm{mo}$ & NC & $\mathrm{HCa}, \mathrm{HCu}$ & pR396W/p.R396W & + & Skalova, Iran J Kidney Dis, 2013 [13] \\
\hline $13-1$ & $6 \mathrm{mo}$ & $\mathrm{NC}$ & $\mathrm{HCa}, \mathrm{HCu}$ & gross deletion exon 9-11 & + & Castanet, J Pediatr, 2013 [5] \\
\hline $13-2$ & asympt & normal & NA & gross deletion exon 9-11 & - & Castanet, J Pediatr, 2013 \\
\hline $14-1$ & $5 \mathrm{mo}$ & NC & $\mathrm{HCa}, \mathrm{HCu}$ & $\mathrm{pW} 134 \mathrm{G} / \mathrm{pR} 396 \mathrm{~W}$ & + & Dinour, Pediatr Nephrol, 2015 [10] \\
\hline $15-1$ & $9 \mathrm{mo}$ & $\mathrm{NC}$ & $\mathrm{HCa}, \mathrm{HCu}$ & pW134G/pE315* & + & Dinour, Pediatr Nephrol, 2015 \\
\hline $16-1$ & $5 \mathrm{mo}$ & $\mathrm{NC}$ & $\mathrm{HCa}, \mathrm{HCu}$ & pE143del/pE143del & + & Dinour, Pediatr Nephrol, 2015 \\
\hline $17-1$ & $18 \mathrm{y}, \mathrm{dx} 35 \mathrm{y}$ & rec UL, NC & $\mathrm{HCa}, \mathrm{HCu}$ & pE143del/pE143del & + (late) & Dinour, Pediatr Nephrol, 2015 \\
\hline $18-1$ & $19 \mathrm{y}$ & rec UL & $\mathrm{HCa}, \mathrm{HCu}$ & pE143del/pE143del & - & Streeten, N Engl J Med, 2011 [14] \\
\hline $19-1$ & $44 \mathrm{y}$ & rec UL & $\mathrm{HCa}, \mathrm{HCu}$ & $\begin{array}{l}\text { c. } 732+1 G>A / \text { c. } 845- \\
2 A>G\end{array}$ & $?$ & Tebben, J Clin Endocr Metab, 2012 [8] \\
\hline $20-1$ & $25 \mathrm{y}$ & rec UL & $\mathrm{HCa}, \mathrm{HCu}$ & $\mathrm{pE} 143 \mathrm{del} / \mathrm{pL} 409 \mathrm{~S}$ & - & Nesterova, CJASN, 2013 \\
\hline $21-1$ & $9 y$ & $\begin{array}{l}\text { UL, NC, } \\
\text { CKD }\end{array}$ & $\mathrm{HCa}, \mathrm{HCu}$ & $\mathrm{pE} 143 \mathrm{del} / \mathrm{pE} 143 \mathrm{del}$ & - & Dinour, J Urol, 2013 [4] \\
\hline $21-2$ & $\begin{array}{l}\text { asympt, } \\
\text { mother }\end{array}$ & $?$ & $\mathrm{HCa}$ & pE143del/pE143del & + (late) & Dinour, J Urol. 2013 \\
\hline $22-1$ & $19 y$ & rec UL & $\mathrm{HCa}, \mathrm{HCu}$ & pW268*/p.L409S & - & Dinour, J Urol. 2013 \\
\hline $22-2$ & $13 \mathrm{y}$ & rec UL, NC & $\mathrm{HCa}, \mathrm{HCu}$ & pW268*/p.L409S & + (late) & Dinour, J Urol. 2013 \\
\hline $23-1$ & $20 \mathrm{y}$ & rec UL, CKD & $\mathrm{HCa}, \mathrm{HCu}$ & pE143del/pE143del & & Dinour, Pediatr Nephrol, 2015 \\
\hline $24-1$ & $18 \mathrm{y}$ & rec UL & $\mathrm{HCa}, \mathrm{HCu}$ & pR396W/p.R396W & & Dinour, Pediatr Nephrol, 2015 \\
\hline $25-1$ & $18 \mathrm{y}$ & rec UL & $(\mathrm{HCa}) \mathrm{HCu}$ & pE143del/pR396W & - & Wolf, Endocr Pract. 2014 [15] \\
\hline $26-1$ & $3 \mathrm{mo}, \mathrm{dx} 29 \mathrm{y}$ & $\mathrm{NC}, \mathrm{CKD}$ & $\mathrm{HCa}, \mathrm{HCu}$ & pW210R/p.W210R & + & Meusburger, Clin Kidney J, 2013 [16] \\
\hline $27-1$ & $20 y$ & rec UL, CKD & $\mathrm{HCa}, \mathrm{HCu}$ & pE143del/ pE143del & - & Jacobs, J Clin Endocr Metab,2014 [17] \\
\hline $28-1$ & $10 \mathrm{y}, \mathrm{dx} 45 \mathrm{y}$ & rec UL, NC & $\mathrm{HCa}, \mathrm{HCu}$ & pE143del/ pE143del & - & Dowen, Kidney Int, 2014 [18] \\
\hline $29-1$ & $45 y$ & $\mathrm{NC}$ & $\mathrm{HCa}, \mathrm{HCu}$ & p.E469fs*22/ p.P21fs*8 & + & Figueres, Am J Kidney Dis, 2015 [19] \\
\hline $30-1$ & $32 \mathrm{y}$ & NC, UL & $\mathrm{HCa}, \mathrm{HCu}$ & p.L409S/ p.R157W & - & Figueres, Am J Kidney Dis, 2015 \\
\hline $31-1$ & $28 \mathrm{~d}$ & $\mathrm{NC}$ & $\mathrm{HCa}, \mathrm{HCu}$ & p.R157W/p.M374T & + & Figueres, Am J Kidney Dis, 2015 \\
\hline $32-1$ & $2 \mathrm{mo}$ & $\mathrm{NC}$ & $\mathrm{HCa}, \mathrm{HCu}$ & p.L409S/ p.R396W & + & Figueres, Am J Kidney Dis, 2015 \\
\hline $33-1$ & $6 \mathrm{mo}$ & $\mathrm{NC}$ & $\mathrm{HCa}, \mathrm{HCu}$ & p.L409S/ p.L409S & + & Figueres, Am J Kidney Dis, 2015 \\
\hline $34-1$ & $2 \mathrm{mo}$ & $\mathrm{NC}$ & $\mathrm{HCa}, \mathrm{HCu}$ & p.R396W/ p.R396Q & + & Figueres, Am J Kidney Dis, 2015 \\
\hline $35-1$ & $6 \mathrm{mo}$ & $\mathrm{NC}$ & $\mathrm{HCa}, \mathrm{HCu}$ & p.E143del/p.L409S & + & Figueres, Am J Kidney Dis, 2015 \\
\hline $36-1$ & $24 \mathrm{y}$ & $\mathrm{NC}, \mathrm{CKD}$ & $\mathrm{HCa}$ & pE143del/ pE143del & + & this paper \\
\hline $36-2$ & asympt & $\mathrm{NC}$ & WNL & pE143del/pE143del & + & this paper \\
\hline
\end{tabular}

Rec recurrent UL urolithiasis; NC nephrocalcinosis, HCa hypercalcemia, HCu hypercalciuria; mo months; y years; dx diagnosed with xx years; WNL within normal limits, + (late) Vit D supplementation beyond infancy

\section{Material and Methods}

\section{Patients}

We studied two related patients from a consanguineous family of Eastern Mediterranean origin. All reported individuals gave informed, written consent to genetic analysis and scientific publication under strictly anonymous fashion.

\section{Clinical, imaging and laboratory studies}

All studies reported used the routine diagnostic facilities of two hospitals. Genetic analysis was performed by standard Sanger sequencing of the entire CYP24A1 gene in the index patient and targeted exon 2 analysis of all other family members. 


\section{Kidney \\ Blood Pressure \\ Research}

Kidney Blood Press Res 2015;40:443-451

DOI: $10.1159 / 000368520$

Published online: August 22, 2015

(c) 2015 S. Karger AG, Basel

www.karger.com/kbr

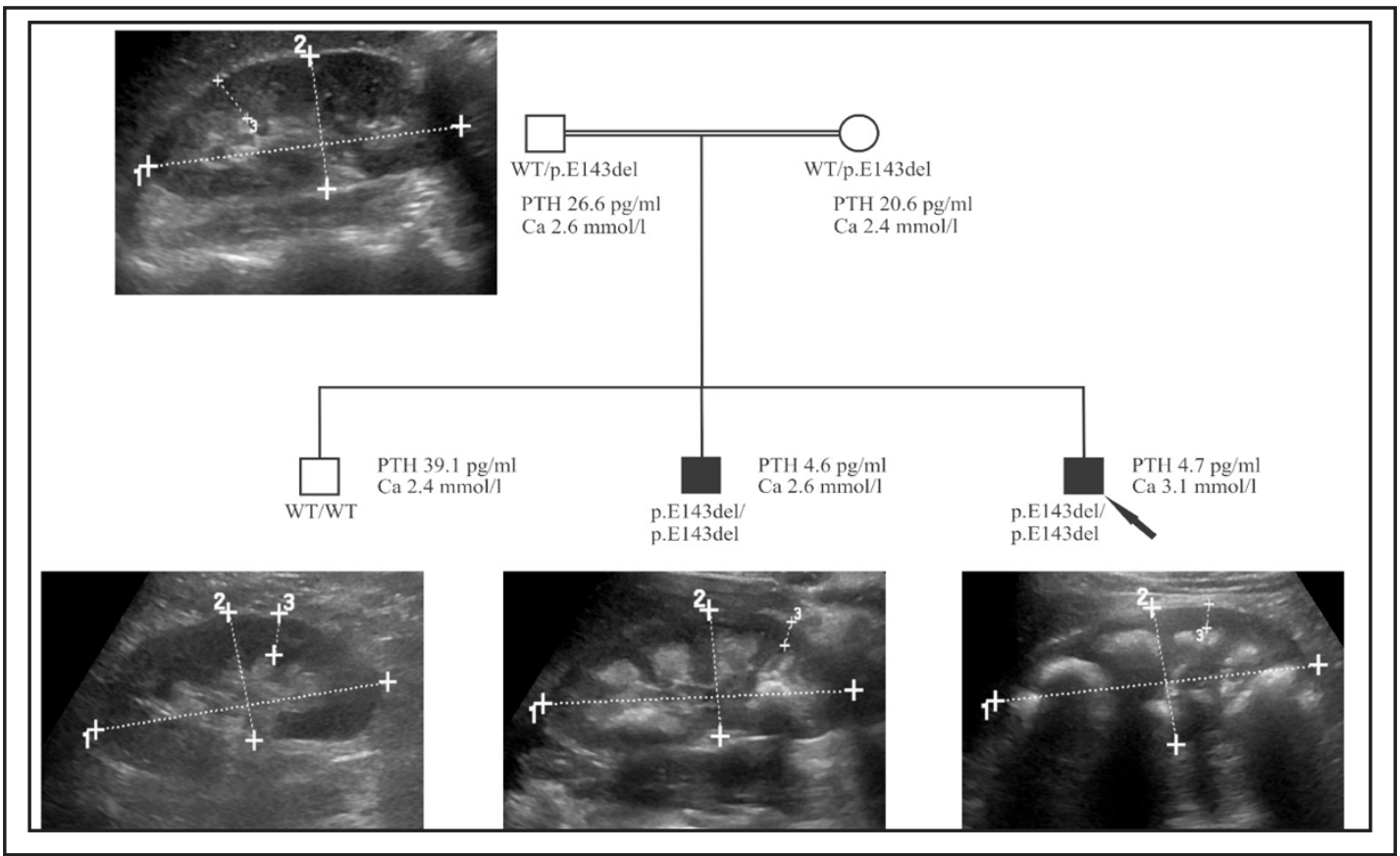

Fig. 1. Pedigree and clinical key findings. The index patient (arrow) is homozygous for the CYP24A1 mutation, as is his 28 year old brother (p.E143del/p.E143del). The parents are heterozygous (WT/p. E143del) for the CYP24A1 mutation and the third brother is not affected, displaying the wild-type allele homozygously (WT/WT). Both affected brothers show suppressed PTH levels (normal value 15-65 pg/ $\mathrm{ml}$ ), but hypercalcemia is an inconsistent finding. The mildly affected brother shows moderate medullary enhancement on ultrasound, whereas the index patient has profound medullary calcifications.

\section{Results}

\section{Patient's history}

The 24-year-old index patient presented generally unwell with fever, odynophagia, diarrhea and volume depletion. He appeared agitated, yet was fully orientated and showed no neurological abnormalities. The preclinical medical history was unremarkable, yet two months before admission the patient presented at his general practitioner with mild arterial hypertension, microscopic hematuria and mild proteinuria on dipstick testing, as well as sterile leucocyturia.

\section{Clinical findings and laboratory results}

The patient showed renal impairment with a serum creatinine of $2.34 \mathrm{mg} / \mathrm{dl}$ and the serum calcium was significantly elevated at $2.92 \mathrm{mmol} / \mathrm{l}$ initially, increasing to $3.1 \mathrm{mmol} / \mathrm{l}$ on follow up. The abdominal ultrasound showed pronounced signal intense kidneys, most strongly at the renal medulla (Figure 1). The decision was made to admit him for further investigations, because of renal failure of unknown cause with hypercalcemia together with signs of infection.

The extended laboratory workup showed no abnormal findings for c and pANCA, ANA, dsDNA antibodies, angiotensin converting enzyme, Quantiferon test. Urine sediment repeatedly showed abacterial leucocyturia without acanthocytes and any crystals. The serology for Epstein Barr virus was suggestive of reactivated infectious mononucleosis, as suspected cause for the recent infection.

PTH was suppressed and $1 \alpha, 25(\mathrm{OH})_{2} \mathrm{D} 3$ was within normal limits $(42 \mathrm{ng} / \mathrm{l})$. The patient displayed normal calciuria, and no abnormal excretion of oxalate or citrate (for detailed 


\section{Kidney Blood Pressure Research}

Jobst-Schwan/Pannes/Schlingmann/Eckardt/Beck/Wiesener: Phenotype Variability in CYP24A1 Disease

Table 3. Laboratory parameters

\begin{tabular}{lccc}
\hline Parameter & $\begin{array}{c}\text { Index patient } \\
\text { E143del/E143del; } \\
\text { Age 24 }\end{array}$ & $\begin{array}{c}\text { Homozygous brother } \\
\text { E143del/E143del; } \\
\text { Age 28 }\end{array}$ & $\begin{array}{c}\text { Standard } \\
\text { value }\end{array}$ \\
\hline Creatinine & $2.34 \mathrm{mg} / \mathrm{dl}$ & $0.92 \mathrm{mg} / \mathrm{dl}$ & $<1.2 \mathrm{mg} / \mathrm{dl}$ \\
Estimated GFR & $34.4 \mathrm{ml} / \mathrm{min}$ & $>60 \mathrm{ml} / \mathrm{min}$ & $>60 \mathrm{ml} / \mathrm{min}$ \\
Urea & $72 \mathrm{mg} / \mathrm{dl}$ & $26 \mathrm{mg} / \mathrm{dl}$ & $17-43 \mathrm{mg} / \mathrm{dl}$ \\
Calcium & $3.1 \mathrm{mmol} / \mathrm{l}$ & $2.6 \mathrm{mmol} / \mathrm{l}$ & $2.1-2.7 \mathrm{mmol} / \mathrm{l}$ \\
Phosphate & $1.13 \mathrm{mmol} / \mathrm{l}$ & $0.97 \mathrm{mmol} / \mathrm{l}$ & $0.81-1.45 \mathrm{mmol} / \mathrm{l}$ \\
Parathyroid hormone (PTH) & $4.7 \mathrm{pg} / \mathrm{ml}$ & $4.6 \mathrm{pg} / \mathrm{ml}$ & $15-65 \mathrm{pg} / \mathrm{ml}$ \\
PTH related peptide & $<1.0 \mathrm{pmol} / \mathrm{l}$ & not determined & $<4.0 \mathrm{pmol} / \mathrm{l}$ \\
1,25-Dihydroxycholecalciferol & $42 \mathrm{ng} / \mathrm{l}$ & not determined & $18.1-70.6 \mathrm{ng} / \mathrm{l}$ \\
25-Hydroxycholecalciferol & $42 \mathrm{ng} / \mathrm{ml}$ & not determined & $30-70 \mathrm{ng} / \mathrm{ml}$ \\
Urinary oxalate & $36.8 \mathrm{mg} / 24 \mathrm{~h}$ & $34.1 \mathrm{mg} / 24 \mathrm{~h}$ & $<44 \mathrm{mg} / 24 \mathrm{~h}$ \\
Urinary citrate & $275 \mathrm{mg} / 24 \mathrm{~h}$ & $218 \mathrm{mg} / 24 \mathrm{~h}$ & $241-531 \mathrm{mg} / 24 \mathrm{~h}$ \\
Urinary calcium & $3.5 \mathrm{mmol} / 24 \mathrm{~h}$ & $2.6 \mathrm{mmol} / 24 \mathrm{~h}$ & $2.5-7.5 \mathrm{mmol} / 24 \mathrm{~h}$ \\
Urinary phosphate & $0.32 . \mathrm{g} / 24 \mathrm{~h}$ & $0.24 \mathrm{~g} / 24 \mathrm{~h} *$ & $0.6-1.2 \mathrm{~g} / 24 \mathrm{~h}$ \\
\hline *possibly inappropriate sampling with only $900 \mathrm{ml}$ of urine \\
\hline \multicolumn{4}{c}{} \\
\hline
\end{tabular}

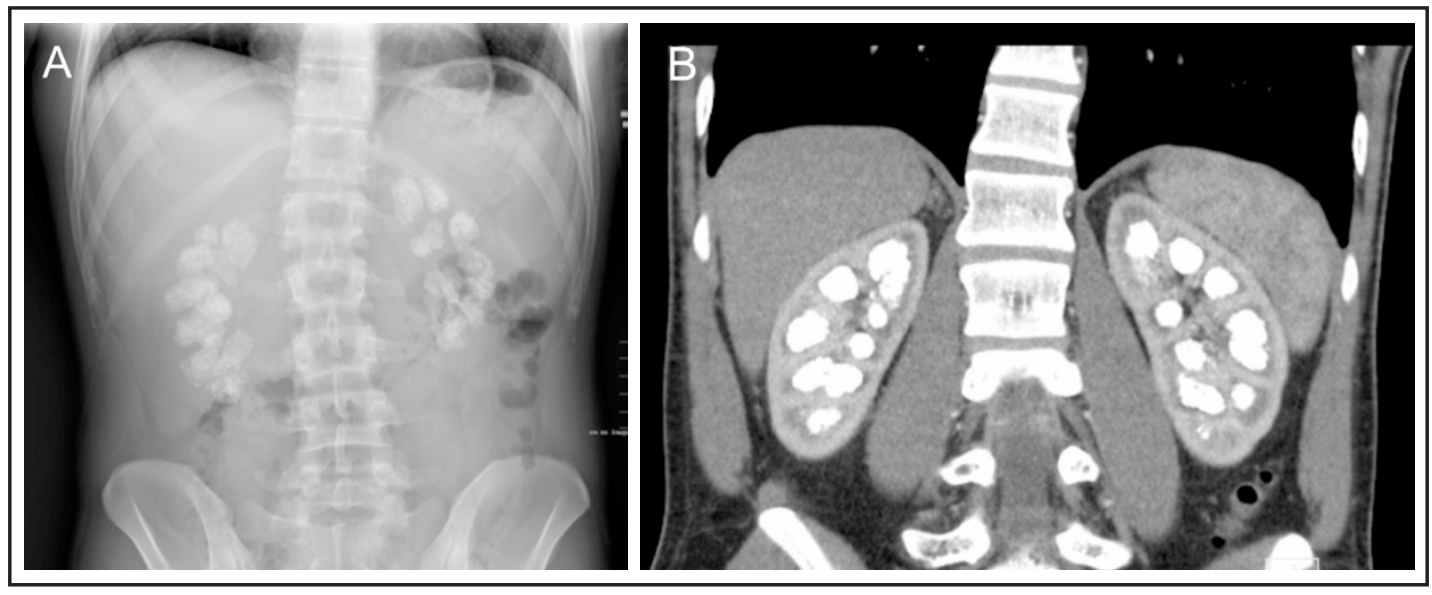

Fig. 2. Imaging studies displaying the index patient's nephrocalcinosis. (A) Distinct medullary calcification in conventional abdominal x-ray. (B) Abdominal computed tomography (CT) without contrast medium showing the calcified medullary pyramids.

laboratory parameters see Table 3). He negated the intake of vitamin D and / or calcium containing dietary supplements.

Abdominal x-ray and CT displayed symmetric calcification of the medullary pyramids of both kidneys, typical for Grade III nephrocalcinosis (Figure 2). No solitary kidney stones were found.

Under treatment with intravenous Pamidronate and loop diuretics with fluid load the patient's creatinine slightly improved and the serum calcium moderately decreased. Thus, the patient was dismissed with a serum calcium of $2.5 \mathrm{mmol} / \mathrm{l}$, continuing the next few months with Pamidronate and recommendations for dietary restriction of calcium and vitamin D. Two years after initial presentation abacterial leucocyturia and light proteinuria were persistent and serum creatinine increased to $1.7 \mathrm{mg} / \mathrm{dl}$, which would be classified as chronic kidney disease (CKD) stage 3 (estimated GFR $49 \mathrm{ml} / \mathrm{min}$ ). Serum calcium was mildly elevated at $2.7 \mathrm{mmol} / \mathrm{l}$. 


\section{Kidney Blood Pressure Research}

Kidney Blood Press Res 2015;40:443-451

\begin{tabular}{l|l}
\hline DOI: $10.1159 / 000368520$ & (C) 2015 S. Karger AG, Basel
\end{tabular}

Published online: August 22, 2015

www.karger.com/kbr

Family studies and genetic analysis

The consanguineous family history was suspicious for an autosomal recessive disease. The clinical picture with NC, hypercalcemia and suppressed PTH primarily led us to analyze for IHH. Direct Sanger sequencing of the CYP24A1 gene revealed the previously described [4] c.428_430delAAG (p. E143del) mutation in homozygous state in the index patient and his clinically asymptomatic older brother who demonstrated milder medullary NC (Grade I) and persistently low PTH levels in the absence of hypercalcemia and hypercalciuria (Table 3, Figure 1).

As expected both parents are heterozygous carriers of p.E143del, while the third brother being completely unremarkable with regard to clinical, biochemical and ultrasound findings is homozygous for the wild type allele (Figure 1).

Interestingly, all three brothers are reported to have received prophylactic oral and daily Vitamin D supplementation by the pediatrician during the first year of life.

\section{Discussion}

As described above, a reasonably large spectrum of diseases should be considered when encountering patients with hypercalcemia and nephrocalcinosis (NC). Important clues leading to the diagnosis in this case were consanguinity of the parents and consistent suppression of PTH in affected siblings. However, this interesting family shows clearly that the phenotype can be highly variable and thus the diagnosis missed when genetic testing is not performed. First, neither hypercalciuria, nor elevation of 1,25-dihydroxy vitamin D3 were seen in any sibling homozygous for the CYP24A1 mutation, where the former has also been reported in single cases by others $([4,5]-$ see Table 2$)$. Second, hypercalcemia is not a consistent finding, but may be influenced by alimentary factors and other stressors, such as infections and / or acute renal failure. Third, the two affected brothers show greatly differing clinical courses, where the older brother may not have been diagnosed during life-time, if family testing had not been performed. At least in this family, PTH appeared to be the most sensitive laboratory parameter and imaging with ultrasound and / or CT appeared helpful.

In view of the greatly variable phenotype of the disease, it is noteworthy that many patients may experience first clinical complications and diagnosis only in adulthood and not in infancy, as has been initially reported. About $30 \%$ of the cases published so far (Table 2) manifest or are diagnosed in adolescence or adulthood. Whether or not any given individual with biallelic inactivation of CYP24A1 encounters clinical consequences, may depend largely on dietary influences such as calcium and vitamin D intake, but also on other genetic variables, such as calcium receptor sensitivity. However, the type of mutation may also contribute to the variability of disease, in the sense of genotype-phenotype association. The mutation found in the current family p. E143del in exon 2 of the CYP24A1 gene affects the CYP450 domain and seems to alter the secondary structure of the substrate binding cavity by preventing a structural bond with the amino acid K283. The lost bondage destabilizes the B'/C loop and leads to a reorientation of the B'-helix (see supplemental figure of [3]) and a complete loss-of-function of the enzyme. A number of other mutations have been identified in other families, where most but not all are missense mutations (see Table 2). To what extent these mutations result in variation of enzyme activity and thereby contribute to disease severity is not known to date.

Interestingly, homozygous Cyp24a1 knockout mice that show elevated $1 \alpha, 25(\mathrm{OH})_{2} \mathrm{D} 3$ levels die before weaning [6]. Their homozygous littermates that survive weaning show even 3 -fold reduced $1 \alpha 25(\mathrm{OH})_{2}$ D3 levels compared to wild type mice. Masuda et al. [7] suggest an unknown alternative pathway of Vitamin D metabolism or a reduced renal $1 \alpha, 25(\mathrm{OH})_{2} \mathrm{D} 3$ production in these mice. Despite these uncertainties, knowledge of a risk genotype may be valuable in reducing life-time risks by relatively simple dietary restrictions, avoiding high amounts of calcium and Vitamin D. Since the content of one or the other can 


\section{Kidney \\ Blood Pressure Research}

Kidney Blood Press Res 2015;40:443-451

\begin{tabular}{l|l}
\hline DOI: $10.1159 / 000368520$ & (c) 2015 S. Karger AG, Basel
\end{tabular}

Published online: August 22, 2015

www.karger.com $/ \mathrm{kbr}$

Jobst-Schwan/Pannes/Schlingmann/Eckardt/Beck/Wiesener: Phenotype Variability in CYP24A1 Disease

be surprisingly high in particular diets, we would emphasize the necessity of a professional dietary consultation.

Furthermore, in severely affected patients, treatment with the cytochrome $3 \mathrm{~A}$ inhibitor ketoconazole may be beneficial, not only in reducing hypercalciuria and hypercalcemia, but also renal insufficiency $[4,8]$. However, frequent and significant liver toxicity may hamper long term use in these patients. Other treatment options may be bisphosphonates, as given to the index patient, or high volume intake with or without the use of loop diuretics. None of these strategies have been tested in a randomized fashion, but this may be worthwhile in the future.

\section{Conclusion}

Importantly, the disease termed idiopathic infantile hypercalcemia $(\mathrm{IHH})$ may be much more frequent than thought or implicated by its name. Since a significant number of patients manifest late or are diagnosed in adulthood with CYP24A1 associated disease the term IHH should be seen as a misnomer. The allele frequency of inactivating CYP24A1 variants may be unexpectedly high [9]. Thus, this disease should also be suspected in respective nonconsanguine families or sporadic cases, since compound heterozygous cases are described [10].

Furthermore, some heterozygous mutations may also result in a similar disease, following an autosomal dominant trait, however this mode of transmission has been an isolated finding so far[8]. Finally, the CYP24A1-associated disease may also result in kidney stones, which is considerably more frequent than IHH. For all these reasons it is pertinent to implement this disease in routine genetic consultations. Besides giving the patient a distinct diagnosis, this approach would improve our knowledge of the disease, the epidemiology and may help us ameliorate the clinical course of this potentially serious condition.

\section{Disclosure Statement}

The authors declare no conflict of interest.

\section{References}

1 Saarela T, Vaarala A, Lanning P, Koivisto M: Incidence, ultrasonic patterns and resolution of nephrocalcinosis in very low birthweight infants. Acta Paediatr 1999;88:655-660.

2 Wiech T, Hopfer H, Gaspert A, Banyai-Falger S, Hausberg M, Schroder J, Werner M, Mihatsch MJ: Histopathological patterns of nephrocalcinosis: a phosphate type can be distinguished from a calcium type. Nephrol Dial Transplant 2012;27:1122-1131.

3 Schlingmann KP, Kaufmann M, Weber S, Irwin A, Goos C, John U, Misselwitz J, Klaus G, Kuwertz-Broking E, Fehrenbach H, Wingen AM, Guran T, Hoenderop JG, Bindels RJ, Prosser DE, Jones G, Konrad M: Mutations in CYP24A1 and idiopathic infantile hypercalcemia. N Engl J Med 2011;365:410-421.

4 Dinour D, Beckerman P, Ganon L, Tordjman K, Eisenstein Z, Holtzman EJ: Loss-of-Function Mutations of CYP24A1, the Vitamin D 24-Hydroxylase Gene, Cause Long-standing Hypercalciuric Nephrolithiasis and Nephrocalcinosis. J Urol 2013;190:552-557.

5 Castanet M, Mallet E, Kottler ML: Lightwood syndrome revisited with a novel mutation in CYP24 and vitamin D supplement recommendations. J Pediatr 2013;163:1208-1210.

6 St-Arnaud R, Arabian A, Travers R, Barletta F, Raval-Pandya M, Chapin K, Depovere J, Mathieu C, Christakos S, Demay MB, Glorieux FH: Deficient mineralization of intramembranous bone in vitamin D-24-hydroxylase-ablated mice is due to elevated 1,25-dihydroxyvitamin D and not to the absence of 24,25-dihydroxyvitamin D. Endocrinology 2000;141:2658-2666. 


\section{Kidney \\ Blood Pressure Research}

\section{Kidney Blood Press Res 2015;40:443-451}

\begin{tabular}{l|l}
\hline DOI: $10.1159 / 000368520$ & C 2015 S. Karger AG, Basel
\end{tabular}

Published online: August 22, 2015

www.karger.com/kbr

7 Masuda S, Byford V, Arabian A, Sakai Y, Demay MB, St-Arnaud R, Jones G: Altered pharmacokinetics of 1alpha,25-dihydroxyvitamin D3 and 25-hydroxyvitamin D3 in the blood and tissues of the 25-hydroxyvitamin D-24-hydroxylase (Cyp24a1) null mouse. Endocrinology 2005;146:825-834.

8 Tebben PJ, Milliner DS, Horst RL, Harris PC, Singh RJ, Wu Y, Foreman JW, Chelminski PR, Kumar R: Hypercalcemia, hypercalciuria, and elevated calcitriol concentrations with autosomal dominant transmission due to CYP24A1 mutations: effects of ketoconazole therapy. J Clin Endocrinol Metab 2012;97:E423-427.

9 Nesterova G, Malicdan MC, Yasuda K, Sakaki T, Vilboux T, Ciccone C, Horst R, Huang Y, Golas G, Introne W, Huizing M, Adams D, Boerkoel CF, Collins MT, Gahl WA: 1,25-(OH)2D-24 Hydroxylase (CYP24A1) Deficiency as a Cause of Nephrolithiasis. Clin J Am Soc Nephrol 2013;8:649-657.

10 Dinour D, Davidovits M, Aviner S, Ganon L, Michael L, Modan-Moses D, Vered I, Bibi H, Frishberg Y, Holtzman EJ: Maternal and infantile hypercalcemia caused by vitamin-D-hydroxylase mutations and vitamin D intake. Pediatr Nephrol 2015;30:145-152.

11 Dauber A, Nguyen TT, Sochett E, Cole DE, Horst R, Abrams SA, Carpenter TO, Hirschhorn JN: Genetic defect in CYP24A1, the vitamin D 24-hydroxylase gene, in a patient with severe infantile hypercalcemia. J Clin Endocrinol Metab 2012;97:E268-274.

12 Fencl F, Blahova K, Schlingmann KP, Konrad M, Seeman T: Severe hypercalcemic crisis in an infant with idiopathic infantile hypercalcemia caused by mutation in CYP24A1 gene. Eur J Pediatr 2013;172:45-49.

13 Skalova S, Cerna L, Bayer M, Kutilek S, Konrad M, Schlingmann KP: Intravenous pamidronate in the treatment of severe idiopathic infantile hypercalcemia. Iran J Kidney Dis 2013;7:160-164.

14 Streeten EA, Zarbalian K, Damcott CM: CYP24A1 mutations in idiopathic infantile hypercalcemia. N Engl J Med 2011;365:1741-1742; author reply 1742-1743.

15 Wolf P, Muller-Sacherer T, Baumgartner-Parzer S, Winhofer Y, Kroo J, Gessl A, Luger A, Krebs M: A Case of "Late-Onset" Idiopathic Infantile Hypercalcemia Secondary to Mutations in the CYP24A1 Gene. Endocr Pract 2014;20:e91-95.

16 Meusburger E, Mundlein A, Zitt E, Obermayer-Pietsch B, Kotzot D, Lhotta K: Medullary nephrocalcinosis in an adult patient with idiopathic infantile hypercalcaemia and a novel CYP24A1 mutation. Clin Kidney J 2013;6:211-215.

17 Jacobs TP, Kaufman M, Jones G, Kumar R, Schlingmann KP, Shapses S, Bilezikian JP: A lifetime of hypercalcemia and hypercalciuria, finally explained. J Clin Endocrinol Metab 2014;99:708-712.

18 Dowen FE, Sayers JA, Hynes AM, Sayer JA: CYP24A1 mutation leading to nephrocalcinosis. Kidney Int 2014;85:1475.

19 Figueres ML, Linglart A, Bienaime F, Allain-Launay E, Roussey-Kessler G, Ryckewaert A, Kottler ML, Hourmant M: Kidney function and influence of sunlight exposure in patients with impaired 24-hydroxylation of vitamin D due to CYP24A1 mutations. Am J Kidney Dis 2015;65:122-126. 